\title{
2. The Uncanny Child of the Millennial Turn
}

\begin{abstract}
Chapter Two focuses on two American films released in 1999, THE SiXTH Sense (M. Night Shyamalan) and STIR of Echoes (David Koepp) to illustrate how, at the cusp of the millennium, the uncanny child character became a precisely realized embodiment of the adult protagonist's personal trauma. These films engage with anxieties of the period: in 1999, the imminent transition into the new century - and millennium - was a strongly felt condition that unsettled a naturalized sense of temporal, personal, and historical progression. The chapter then turns to a later amplification of this trend, INSIDIOUs (James Wan, 2010), in which the uncanny child's imbrication with the adult patriarch's trauma is self-reflexively addressed.
\end{abstract}

Keywords: Uncanny, Childhood, Trauma, Secret, Millennial turn, The Sixth Sense

The uncanny child cycle was reignited in the U.S. at the cusp of the millennium by The Sixth Sense (Shyamalan) and Stir of Echoes (Koepp), released within months of each other in 1999. In particular, THE SIXTH SENSE was the second highest-grossing film of the year, earning \$293 million at the box office behind only the highly anticipated STAR WARS EPISODE 1: The Phantom Menace (George Lucas) (Kendrick, 2010, 142). As James Kendrick points out, the horror genre had not produced a blockbuster of this cultural and financial magnitude since Jaws (Steven Spielberg, 1975), and, prior to that, THE ExORCIST. He asserts that:

the cycle of films that emerged in the wake of THE SIXTH SENSE is particularly important and worthy of attention because, not only was it extremely concentrated, but it marked a decided shift in the horror genre as it was currently constituted, which served a dual function. First, in terms of 
the films themselves, it refreshed the genre by returning it to its initial emphasis on the psychological and the spiritual over the material and physical. [...] Second, in economic terms, this shift in the genre attempted to mainstream horror films (a historically marginalized genre associated with independent studios and B-level production values) by giving them a potentially broader audience via their typical PG-13 ratings and more conventional emotional resonances. $(2010,143)$

I contest Kendrick's term 'conventional emotional resonances' as this supernatural cycle of films expresses complex millennial anxieties, and STIR of Echoes is rated R (which Kendrick concedes). I concur, however, that The Sixth Sense and Stir of Echoes helped to incite a millennial boom in gothic ghost films ${ }^{1}$ that became a globally recognized, mainstream phenomenon - evidence of the extent to which this cycle resonated with contemporary anxieties. As Kendrick and others, such as Hantke (2010), have pointed out, the American horror genre was seen to be in crisis by the end of the 1990s after two decades of slasher and 'post'-slasher franchises, so the pervasive success of The Sixth SEnse heralded a new trajectory for the genre. The critical and economic success of other films discussed in subsequent chapters indicates the extent to which this late 1990s/early 200os supernatural horror revival constellated around the uncanny child.

The Sixth Sense and Stir of Echoes exhibit many of the same devices as The Shining, The Changeling, and Poltergeist, as the uncanny children and their spectral insights are entangled with the psyches of the protagonists in quite precise ways. In addition, these films emerge at a juncture in which vague fears about the solidity of reality and the transition from present into future permeated the American cultural consciousness, just as in the early 1980s. In 1999, the imminent transition into the new century - and millennium - was a strongly felt condition that unsettled a naturalized sense of temporal and historical progression. For instance, in his book published in 1998 meditating on the impending millennial shift, Joseph Natoli wonders, 'are we crawling toward our own end beyond the horizon of the New Millennium?'(6). He elucidates that 'the closer we come to the millennium the greater our sense of heading not into a dream but into an abyss' (Natoli, 1998, 12). As Kendrick suggests, this anxiety about

1 The most significant of these films are discussed in this book. Others include THE HAUNTING (Jan de Bont, 1999), House on Haunted Hill (William Malone, 1999), What Lies Beneath (Robert Zemeckis, 2000), The Gift (Sam Raimi, 200o), and Thi13Een GHosts (Steve Beck, 2001). 
the transition into the 21st century resulted in a phenomenon in which, in the final years of the 199os, 'it seemed that the entire American film industry was caught up in fin-de-siècle-inspired renewal of spirituality and religion that infiltrated virtually every genre' $(2010,150)$. While these supernatural films are not all fixated on the status of religious belief although indeed, some, such as FALLEN (Gregory Hoblit, 1999) and STIGMATA (Rupert Wainwright, 1999), pivot on this theme - they are united through their uneasiness about wavering understandings of 'the real' and the subsequent inability of adult subjects to grasp at the secrets of their own existence. This theme pervades numerous films spanning varied genres in 1999, including Fight Clu b (David Fincher), The Matrix (Lily and Lana Wachowski), The Thirteenth Floor (Josef Rusnak), Eyes Wide Shut (Kubrick's last film), MAGnolia (Paul Thomas Anderson), and EXIstenZ (David Cronenberg).

The uncanny children in The Sixth Sense and Stir of Echoes are similarly bound up with millennial anxieties about the status of cohesive self-identity and contemporary ideological structures - and whether or not these structures will continue into the new millennium, a threshold of futurity that felt eerily tangible. As Jeffrey Weinstock suggests, it is:

no coincidence that the contemporary American fascination with ghosts seems to have reached a high-water mark at the turn of the millennium. [...] The millennial explosion of supernatural cultural production [...] seems to suggest that what is as frightening as the unknown field of the future is the tenacious tendrils of a past we cannot shake. $(2004,6)$

Furthermore, these films, like The Shining, The Changeling, and PolterGEIST before them, position the spectres and the uncanny children who draw them forth as ambiguous threats to the power and primacy of patriarchal identities, illuminating the extent to which the anxieties associated with the imminent transition into the 2ooos circulated again around shifting, or, more specifically, declining, male power. As Fintan Walsh elucidates, since the 1990s, 'men have increasingly appeared across a range of social and aesthetic practices as troubled subjects, with Western masculinity repeatedly reported to be in a critical state' $(2010,3)$ a phenomenon he sees expressed in films like Fight CLU в at 'the height of the decade's deconstruction' (7).

As in the early 1980s, this felt sense of symbolic crisis was closely entwined with questions surrounding the nature of childhood. These two films from 1999 aestheticize power shifts between child and adult, centred as in THE 
Shining, The Changeling, and Poltergeist on the child's supernaturally charged insight and the ways this gift empowers the child to approach the deepest alcoves of both reality and the protagonist's psyche. This process - realized in ways more urgent and precise than in the 1980 s films - can be related to the anxieties Kincaid so powerfully charts in his Erotic Innocence, first published in 1998. As he suggests, 'few stories in our culture right now are as popular as those of child molesting' (1998, 3). Indeed, by the late 199os, the ambivalent moral panic about child abuse reached a crescendo: as Philip Jenkins suggests in his book Moral Panic, also published in 1998, by the late 1990s, one of the most entrenched 'self-evident facts in contemporary America is the belief that children face a grave danger in the form of sexual abuse and molestation' (1998, 1).

While most millennial uncanny child films do not overtly address child sexual abuse as a central theme, cultural concerns about the dark secrets possessed by adulthood's 'inner child' recharged the psychic, temporally tangled entwinement of child and adult psyches seen in uncanny child films of the early 1980s. Kincaid suggests that associated with the cultural fixation with widespread child abuse is a sense that everyone has traumatic memories from childhood hidden within the most unattainable depths of our minds. In his words, these stories thus press 'our origins into the realm of sorrow and pain - we always spring from abuse' (1998, 251). As he explains:

By expanding the story of child molesting into the past and into the recesses of all our memories, we make sure no one is left out. [...] Child molesting is an epidemic, and memory holds the secret. [...] Memory guards the vault. The fact that memory may not yield up the secrets readily licenses us to talk at greater length about hidden pasts. $(1998,244)$

Kincaid traces how the cultural fixation with this process led to an explosion in popular discourse suggesting that 'we must find that inner child and attend to its needs' $(1998,70)$ - as popularized throughout the 1990s in popular media such as Oprah Winfrey's ScAred Silent: Exposing AND ENDING CHILd ABUse, broadcast across all American television networks in 1992. This rhetoric situates the quest to uncover one's 'inner child' as a fraught but vital process synonymous with excavating the buried secrets of one's psyche. In The SIXTH SENSE and STIR of EchOES, the child quite clearly functions as the symbolic vessel or 'stage' for the adult's repressed psychic content, as the protagonist's burgeoning recognition that a mysterious spectral realm underlies normality is played out through his deeply personal quest to uncover what the child character conceals. 


\section{'You've got a secret that you don't want to tell me': The SiXTH SENSE}

In The Sixth Sense, adult protagonist Malcolm Crowe is a child psychiatrist, thus unravelling the riddles of childhood is no longer presented as a symptom of the ghost narrative but is positioned as an overtly central preoccupation. ${ }^{2}$ The dramatic twist in the final scene of the film reveals that the analysis of the child's 'phobia' leads to a revelation within the adult protagonist as well, clearly refracting the mechanics promulgated by Freud's 'Little Hans' case, discussed in the previous chapter, whereby the child's hieroglyphs are conflated with concealed truths within the adult mind. This impression is heightened by the narrative structure of THE SiXTH SENSE, in which the twist in the final scene shifts the meaning of all that has happened before. If the film's narrative 'pulling the rug out' from under the audience functions as intended, at the climax of the film, both Malcolm and the viewer simultaneously become privy to a further layer of Cole Sear's secret previously inaccessible to us: that Malcolm has been dead since the beginning of the film. Thus, the quest to uncover the child's secret becomes sewed into both the narrative and visceral experience of the film. The advertising taglines for the film played upon this process, reading 'Discover the secret of The Sixth Sense!', 'Do you believe now?', and 'Can you Keep the Secret?'

\section{Cole and Malcolm's Traumatic 'Secret'}

As in the films considered in Chapter One, the obstructed channel of communication between child and adult is a source of anxiety in THE SIXTH SENSE, for it impedes Malcolm's quest to uncover Cole's secrets. Echoing Danny's 'REDRUM', Cole issues hieroglyphs that Malcolm (and the viewer) must decode, a process emphasized in light of the twist, which reveals that many of Cole's previous statements conceal another layer of meaning. This decoding begins as soon as Malcolm meets Cole and hears him speaking in Latin, forcing him to translate the child's speech in order to comprehend it. (The child says 'De profundis clamavi ad te domine', which Malcolm translates as 'Out of the depths I cry to you, Oh Lord'). After Cole finally tells Malcolm his secret halfway through the film - that he sees dead

2 Due to its psychological theme, a number of psychoanalytic readings of the film have been produced: for a Lacanian reading see Coral Houtman (2004), on death and mourning see Marguerite La Caze (2002), and for a discussion about seduction theory and the fairy tale see Jane Thrailkill (2010). 
people - Malcolm does not truly comprehend the child's statement until he carries out his own detective, or analytic, work. Prior to this, the revelation further exposes the gulf of understanding between adult and child: when Cole asks Malcolm if he believes him, Malcolm replies 'I don't know how to answer that, Cole.' Malcolm only becomes convinced of the 'truth' of Cole's secret when he listens to the audiotapes of his sessions with former patient Vincent. Vincent first appears as a blathering madman at the opening of the film, who, having broken into Malcolm's house, suddenly appears half-naked in his bathroom and shoots Malcolm before shooting himself. He is an abject evocation of Malcolm's professional failure, to which Cole figures a return.

While listening to Vincent's session tapes, Malcolm notices a vague murmur on the recording that he had never noticed before. He rewinds the tape repeatedly, gradually increasing the volume to its maximum level, until he finally discerns a ghostly voice speaking to Vincent, partly submerged by static and crying out in Spanish: 'I don't want to die.' ${ }^{3}$ This scene represents a central turning point of the film, as Malcolm finally believes Cole's secret, and also the previously inscrutable truth behind Vincent's 'phobia'. Yet, it is not through direct communication with the child that Malcolm finally comprehends the source of Cole's anxieties, but through a technologically mediated voice from the past. Underscoring the uncanniness of both Vincent and Cole's knowledge, the audio recording from Malcolm's own past turns into a disembodied echo from another realm that reveals a layer of reality that was imperceptible to Malcolm at the time it was recorded. As in The Changeling and Poltergeist, anxieties about the uncanny child's harbouring of urgent secrets that he is unable to communicate lucidly are realized through technology's ability to allow the adult access to the child's previously elusive world, aestheticizing the uncanny amalgamation of separation and connection between child and adult psyches. The audible static that at first hides the ghostly voice metaphorizes the grainy, unclear channel of communication between the two realms.

While both the viewer and Malcolm are led to assume that they have uncovered and come to terms with Cole's secret once it becomes clear that he really does 'see dead people', the twist exposes that Cole has in fact been hiding another secret - one that is not so easily ameliorated. The last of Cole's secrets to be revealed, that Malcolm is one of these dead people, represents a repressed truth within the adult protagonist's own psyche: the hidden quest underlying the surface narrative is Malcolm's journey to understand and come to terms with submerged components of his own (non)being. 
Thus, The Sixth Sense makes overt the uncanny child's symbolic role as receptacle for the adult's repressed trauma. Cole's final secret exposes a further hole or lack within the adult protagonist that disrupts the cohesive narrative of adult fulfilment in an irreparable manner.

Cole functions like a reincarnation of the crisis that has emasculated and undermined Malcolm's coherent identity as an award-winningly successful child psychiatrist: his failure to cure former patient Vincent. Thus, Cole is like uncanny déjà $v u$ for Malcolm and the viewer, an almost literal reevocation of Malcolm's past trauma. Both Vincent and Cole have a patch of grey hair at the back of their heads, symbolizing their access to uncanny knowledge too great for their youth, and, as Malcolm explains, 'They're both so similar. Same mannerisms, same expressions, same things hanging over their head.' Vincent's taunting words at the opening of the film evoke a rupture in Malcolm's patriarchal, professional identity by hinting at his lack of awareness in comparison to Vincent's own knowledge. Notably, the film opens with a scene depicting Malcolm and his wife arriving home from an awards ceremony, where Malcolm has just been bestowed with an award from the Mayor of Philadelphia in 'recognition for his outstanding achievement in the field of child psychology'. The subsequent scene depicts Vincent appearing in the couple's bathroom: 'You don't know so many things' Vincent remarks, and sarcastically undermines Dr. Crowe's paternalistic saviour status by taunting, 'Don't you know me, hero?' Malcolm is unable to talk Vincent into putting down the gun he wields: 'you failed me', he declares before shooting Malcolm and turning the gun on himself.

Functioning as a repetition of this trauma, Cole provides Malcolm with an opportunity to discover the 'so many things' that he does not know, and also to once again become a 'hero'. Thus, Cole functions as a literalization of Malcolm's compulsion to repeat the trauma that has injured his secure conception of self and gain mastery over it. On first viewing, the audience is led to believe that this narrative is the primary one in the film, and that the film is wrapped up when Malcolm finally achieves his goal and becomes Cole's hero, helping Cole to conquer his fear of the ghosts he perceives. However, the final revelation that Cole has been keeping yet another secret from Malcolm - that he has been dead all along, and is thus one of these ghosts - reveals that Malcolm's trauma is actually irrevocable. Malcolm was in fact killed by Vincent at the beginning of the film, thus the adult's 'hole' - literalized by the gunshot wound on his back, which Malcolm realizes is still bleeding as he becomes aware that he is dead - cannot be filled or repaired. This wound is a precise incarnation of Caruth's traumatic 'wound that cries out' and 'simultaneously demands and defies our witness' (1996, 
4-5). All Malcolm can do at the close of the film is disappear, as a close-up of his face fades into the mediated image of him (now his only form of existence in the world as we know it) on the home videotapes of his wedding, which play as his wife sleeps.

\section{Childhood Traumas/Adult Traumas/Social Traumas}

As well as being intertwined with Malcolm's own trauma, Cole's sixth sense is associated with a knowledge of concealed pasts that undermine present American sociocultural structures. Magnifying the implications of the children's spectral powers in The Shining, The Changeling, and Poltergeist, Cole's visions of the aggrieved dead reveal that present adult society is founded on violence and oppression, and depends upon the repression of this truth to function cohesively. Thus, Cole's statement that the ghosts he perceives 'only see what they want to see' can be applied not only to the ghosts, but to the living adults that surround him as well. As Ted Underwood points out:

[V]isually, the work is nearly as haunted by Philadelphia's past as Cole Sear is by the stories of the dead people he sees. Since the film leaves the young boy with a continuing responsibility to decode injustices reaching back to the eighteenth century, it is difficult to imagine that he will grow up to become anything but a local historian-perhaps the kind of erudite bookstore owner who is consulted in VerTigo about the meaning of masculine power in nineteenth-century San Francisco. $(2002,247)$

However, Cole's ability is represented as a good deal more disruptive than that of a knowledgeable historian, threatening because of his position as a child who sees 'too much' of what underlies adult society. As director Shyamalan states in an interview on the DVD, 'this child has knowledge way beyond what he should'. The film is permeated by the fear that the child sees too much of the adult self, a clear refraction of Freudian discourse that positions childhood as the symbolic site of adulthood's submerged psychic content.

The threat Cole's knowledge poses to adult epistemic structures is revealed in a classroom scene in which Cole confronts his teacher, Mr. Cunningham: a scene that occurs early in the film and establishes Cole's penetrative supernatural insight. The sequence also confronts how the school functions as one of the most powerful institutions of not just child socialization, but of the social othering of the child. Influential childhood theorist Philippe Ariès 
suggests that the development of the modern schooling system was integral to the formation of distinct borders of separation between the child and the adult. As he states, the development of institutions of schooling towards the end of the seventeenth century revolved around conceptions of 'the weakness of childhood [...] [but a weakness] associated with its innocence [...] and which placed education in the front rank of man's obligations' $(1962,111)$. He points out that the Romantic idea of innocence as inherent to childhood resulted in two kinds of attitudes and behaviours towards education that remain central to understandings of the child, 'firstly, safeguarding it against pollution by life, and secondly strengthening it by developing character and reason' $(1962,116)$.

The modern education system is thus structured around 'the association of childhood with primitivism and irrationalism or prelogicism' (Ariès, 1962, 116): a process of institutionalized inferiority that Marina Warner suggests has paradoxically become central to childhood's symbolic power. She asserts that the unreason of children is typically realized in the popular imaginary as an 'intimate connection, above all, to a wonderful, freefloating world of the imagination. Their observable, active fantasy life, their fluid make-believe play seem to give them access to a world of wisdom' (Warner, 1994, 37). THE SiXth SEnSE exposes the gothic underside to this myth. In the classroom scene in the film, Cole empowers his otherness: not yet inculcated into the world of adult reason, Cole's unreason affords him a spectral wisdom that penetrates beyond accepted adult discourse.

In the scene, Mr. Cunningham is teaching a history lesson about the school building, and he explains to the class that 'almost any place you go in this city has a history, a story behind it'. When questioned about what the story behind the building may be, Cole proclaims that it was used for public hangings. The visibly uncomfortable teacher rejects his answer, telling him that it is not 'correct', as if only a single historical narrative is acceptable. Cole counters the teacher, delving deeper into the grisly past of the school by explaining that 'they'd drag them in crying and kissing their families bye. People watching them would spit at them.' Cole's explanation of the school's violent past (to which the audience also later becomes witness, as we see the bodies of a hanged family swinging from a beam in the school's ceiling) is counteracted with the teacher's explanation that 'this building was a legal courthouse. Laws were passed here, some of the very first laws of this country.' The teacher thus dismisses Cole's history to replace it with a neat and clean version, one that valorizes the formation of America's symbolic reality while eliding the violence and oppression bound up with its creation. Yet, as the audience has at this point developed a burgeoning 
awareness of the extent of Cole's grisly knowledge, it is implied that the story the teacher espouses subscribes to a revisionist historical narrative that is tightly controlled by (powerful) adults in the present. Notably, images of the busts of America's presidents are neatly lined up in chronological order on top of the blackboard above the teacher's head, representative of an orderly and idealistic progression of American history.

Cole's insistent alternative answer reveals the narrowness of this history, and highlights how this historical narrative is 'correct' only because the adult teacher proclaims it is so. The teacher goes on to explain that the whole building was filled with 'lawyers' and 'lawmakers', to which Cole promptly responds, 'they were the ones that hanged everybody', subverting the paternalistic authority of the 'lawmakers' by exposing it as violently oppressive. The teacher further disallows Cole's version of historical events, telling him 'I dunno which one of these guys told you that, but they were just trying to scare you', while smirking in a way intended as comforting but which, as filmed in a low-angle shot that places the viewer into Cole's own lowly position, appears patronizing; especially in light of Cole's insights, the teacher's wielding of his position of authority now seems overbearing and disdainful. Cole responds by angrily crying 'I don't like people looking at me like that, stop it!', yet the teacher continues to advance, maintaining a condescending stare, and remarks 'I don't know how else to look.' Frustratingly for Cole, the teacher's only optique through which to perceive the child is to look down upon him as a subjugated other.

Cole continues to defy his subordinate position by further flaunting his surplus knowledge, revealing that he is also in possession of a repressed secret about Mr. Cunningham's own past: that he stuttered as a child. Thus, as occurs on a grander scale in the relationship between Malcolm and Cole, the child's association with a spectral realm becomes conflated with the reemergence of a painful past from the depths of the adult's psyche, in a simultaneous disruption to both linear historical metanarratives and to the image of a stable and superior adult self - the apparent 'end goal' of the teleological process of growing up. The teacher's repressed 'inner child' returns with a vengeance as Cole repeatedly shouts 'Stuttering Stanley!', and Mr. Cunningham starts to stutter helplessly as all the other children watch on. The stutter breaks through and erodes the teacher's imperious facade. Like trauma itself, the stutter functions as an uncontrollable blockage and repetition that metaphorizes the uncanny reemergence of 'Stuttering Stanley', and diminishes Mr. Cunningham's ability to communicate effectively as an adult. Through his parallel destabilization of the neat temporal borders of history, the adult self, and of the adult's rational chain 
of signification, Cole is again aligned with the hidden abject within the adult, a repressed psychic realm equated with the adult's traumatized inner child.

\section{Cole and the Viewer's Trauma}

This irruption of a fissure in the wholeness and coherence of the adult's subjective reality is echoed by the viewer's own experience of THE SIXTH SENSE, if the twist narrative functions as intended. While on first viewing we are led to believe that we are watching a straightforward ghost story about a paternalistic psychologist helping a young child with an uncanny 'gift', we learn in the final scene that there has been an underlying double reality haunting the surface narrative of the film all along. Central to this twist is the recognition that Cole was always aware of this second reality, but has been concealing it from Malcolm. Thus, in an amplification of the classroom scene, the film's final revelation subverts the balance of power and knowledge between the child and the adult.

Erlend Lavik discusses THE SIXTH SENSE and other twist films in terms of a particular relationship between the syuzhet (the presentation and arrangement of audiovisual information) and the fabula (the whole story/ fictional world that this syuzhet eventually creates). He explains that in such films there is a:

doubling of the syuzhet, where we are led to construct a fabula that initially seems quite straightforward until suddenly a new piece of information is introduced that subverts (or decentres) the fictional world we have created. We come to realize the presence of another fabula running parallel to the first one but 'beneath' it, hidden from view. $(2006,56)$

The revelation that Malcolm has been a ghost all along shatters the fabula that audiences are led to construct upon first viewing the film, a process that parallels Cole's own ability to overthrow accepted realities throughout the film. The impression that an eerie, previously hidden double of conventional experience has bubbled to the surface of our perceptions represents a central facet of the uncanny, enforcing a potent experience of cinematic déjà $v u$. This is of course heightened by the fact that the viewer is compelled to rewatch the film in order to construct the second, and more accurate, fabula. In doing so, the viewer experiences a 'narrative bifurcation whereby we come to notice how traces of the correct fabula were actually available to us the first time' (Lavik, 2006, 59). 
This process of rewatching the film in an attempt to see both how the director left clues to this hidden fabula and to solve the riddles of Malcolm's existence reveals the viewer's own compulsion to repeat, as we are impelled to refocus our detective work around Malcolm in a subversion of Malcolm's analysis of Cole: the exposure of the child's secret thus turns a mirror upon the protagonist and audience that exposes a fracture in the adult's subjectivity. Discussing the structure of the detective story echoed across ghost narratives - Slavoj Žižek explains that 'the detective's role is $[. .$.$] to demonstrate how "the impossible is possible" [...] that is, to$ resymbolize the traumatic shock, to integrate it into symbolic reality' $(1992,58)$. On first viewing, this process is realized through Malcolm's quest to comprehend Cole's secrets, and then to situate the abject ghosts he sees into a secure symbolic framework whereby they 'disappear' if Cole comprehends their requests and subsequently fulfils them. Yet, with the revelation that Malcolm is one of these ghosts, the coherence of the film's symbolic framework is displaced. The compulsion to rewatch the film in order to better understand how Malcolm experiences time, consciousness, and communication (or lack thereof) represents a secondary attempt to impose stable meaning upon the abject space where meaning collapses beyond rational, adult-centric discourse: to clarify the symbolic framework of the diegesis and Malcolm's position within it. However there are many irremediable gaps in Malcolm's experiences - we do not actually see him trying to pay for the bus, or meeting Cole's mother for the first time, or pondering the fact that no other human being has spoken to him for six months apart from Cole - fissures that repeat viewings cannot repair. As we shall see, a similar obstruction to tidy narrative resolution occurs in the final scene of STIR OF EcHOES, a fracture again exposed by the child's uncanny knowledge.

\section{'In every mind there is a door that should never be opened': STIR OF ECHOES}

STIR OF ECHOES revolves around the Witzky family - Tom, Maggie, and their young son Jake - and follows Tom's quest to unravel the secrets behind a mysterious female ghost he begins to see after being hypnotized at a party. This ghost is Samantha, a teenage girl who was murdered accidentally in a rape attempt by two young men who live in the Witzky's neighbourhood, and whose body was hidden in the Witzky's basement before they moved in. While Tom only becomes reacquainted with his latent ability to see 
beyond the limits of linear time after being hypnotized, young Jake possesses supernatural insight that greatly exceeds the perceptual capabilities of his father. Thus, while it is the adult's quest that the film follows, it is once again the child who holds the secrets that must be unravelled to resolve the mysteries of the narrative. Jake becomes implicated in a process of uncanny doubling and déjà vu associated with both his ability to perceive multiple layers of temporality and his function as the receptacle for the enigmas of his father's own mind.

The 'stir of echoes' of the film's title is metonymized by a song that repeatedly reoccurs throughout the film in different forms. The song is associated with Jake, as he hums it in a number of scenes and, at one point, helps his father pick out the correct tabs for it on the guitar. The film opens with this song, as Jake's voice is heard haltingly humming fragments of it as the opening titles appear against a black screen. It sounds like an amalgam of melodies, with momentary hints of 'Ode to Joy' and an array of children's nursery rhymes, while never being truly discernible as any particular tune. Arising out of the black depths of the opening titles without any accompanying visuals, the cuteness and innocence of the song is threateningly undermined as the viewer is invited to question its placement in the opening of a horror movie, an effect heightened by the fragmentary tune's resistance to contextualization. In fact, it is difficult even to determine whether it is in a major or minor key, emphasizing the tune's troubling of childhood sweetness. As Stan Link explains in his discussion of children's musical performances in the diegetic world of horror films, 'at once an ingenuous and dis-ingenuous performance, in [horror films] the sound of innocence frequently announces its own end' $(2010,44)$.

Thus, the uncanny child's performance of innocence evokes suspicions about what grisly knowledge he conceals beneath his cute affectations, constructing the appearance of innocence and cuteness as merely a naive (or wishful) misunderstanding of the child on the part of the adult. In STIR OF Echoes, the vague song of the opening represents the first of the hieroglyphs that the uncanny child issues, a riddle that the viewer and adult protagonist are tasked with decoding. The song becomes the key to uncovering the dark secret of the film. Far from being an innocent nursery rhyme, it is revealed in the film's climactic scene to be the Rolling Stones's 'Paint it Black' (1966), a cover version of which (performed by Gob, 1998) was played loudly on a stereo by the young men who killed Samantha in an attempt to drown out her screams while they raped her.Jake's humming thus functions as a signifier of the child's impossible knowledge of this violent scene. The lyrics to 'Paint it Black' underscore the child's ability to perceive 
the darkest, suppressed components of adult society with lines such as 'It's not easy facing up when your whole world is black.'

That Jake hums this song in the opening seconds of the film renders his knowledge particularly uncanny when the song's context is finally revealed at the climax. Jake's humming taunts the viewer with the fact that he possessed the grim knowledge needed to solve the film's mystery all along. As if to reinforce this, when Tom finally 'witnesses' Samantha's murder after locating her corpse - experiencing a vision aided by his recently rediscovered clairvoyancy - Jake's voice becomes audible humming along with the music accompanying her death, even though he is not physically present in the scene. The child's humming gradually overcomes the diegetic music on the CD player so that, in Tom's vision, Samantha's final breaths are accompanied solely by Jake's humming of the song. Thus, in the construction of this scene, Jake is vaguely positioned as complicit in the covering up of the girl's murder by withholding this secret. This scene functions as a powerful moment of uncanny déjà vu both for the viewer and Tom, who, at multiple points throughout the film, has cried out in frustration (perhaps in alignment with the viewer) 'Why do I know this song?' and 'What is that song!' in response to Jake's humming. As it finally becomes clear what the song is and why it is significant, déjà vu's vague threats of a double reality haunting that which is visible to us finally become realized. This final and most sinister rendition of Jake's humming also unveils the child's function as an embodiment in the present of the muffled echoes of the past.

\section{'You're awake now, Daddy': Child/Adult Psyches}

The supernatural knowledge and abilities Tom comes to access are aligned with the deepest recesses of his own psyche, as his insight (re)emerges upon being hypnotized. Promotional taglines for the film read 'in every mind there is a door which should never be opened'. In the film, hypnotist Lisa makes the connection even more overt, explaining to Tom that when she hypnotized him, she 'opened a door [...] it releases repressed memories and latent abilities, whatever you got back there'. Thus, STIR OF ECHOEs makes explicit the symbiotic relationship between the uncanny surfacing of ghosts from the past and the reemergence of the adult's repressed mental content: for instance, when Tom is hypnotized, he is simultaneously reacquainted with his supernatural extrasensory perception, and his repressed childhood memories of being bullied. Once again, the child is the nexus of these traumatic resurfacings. Because Tom only sees terrifying and fractured glimpses of the supernatural, he is forced to interrogate Jake in order to comprehend 
his new insight. Thus, as in The Sixth SEnse, the adult protagonist must analyse and excavate the enigmatic riddles of the child in order to resolve tensions and complexes within his own mind (and, subsequently, within the film's narrative).

In this way, Jake functions as a nebulous reoccurrence of Tom's own childhood, embodying Tom's regression into a hidden component of his mind previously inaccessible to him in adulthood. Jake's humming of 'Paint it Black' reinforces his function as a symbolic stage for the adult's submerged memories and psychic abilities. Tom is maddened by his faint memory of the song and his inability to pin it down or contextualize it (at one point, he frantically digs through his CD collection in an attempt to locate it), and his annoyed questioning of 'Why do I know that song?' simultaneously seems to be addressed both inwardly and to Jake.

Tom quickly becomes aware that his son is the key to understanding the unleashed secrets of his mind. When he first encounters the ghostly Samantha after the hypnosis 'opens' his mind, he discovers Jake has been watching him silently from the top of the stairs. 'You're awake now, Daddy', Jake tells his father as he descends the staircase. The child then touches Tom's forehead, and, while giving him a knowing look, advises 'don't be afraid of it, Daddy'. In STIR OF ECHOEs, this conflation of the adult's repressed 'inner child' with latent supernatural powers disrupts nostalgia for the innocent state of childhood, irretrievable as soon as one is an adult. When Tom's mind becomes 'opened', instead of being reacquainted with a world of naïve innocence, he (re)experiences childhood as the locus of fears, urges, and memories he had displaced in adulthood - recalling Kincaid's characterization of the inner child as a 'realm of sorrow and pain' (1998, 251) - an extension of the conceptual links drawn in uncanny child films of the early 1980 s.

Initially, it appears as though the film's quest is resolved once Tom finally uncovers Samantha's body and discovers the truth behind her murder: the ghost's secret has been revealed and those responsible have been punished, releasing the ghost Samantha from her basement tomb. Furthermore, it appears that Tom's visions have subsided, and the Witzky family have decided to move away from what has now been exposed as a corrupt neighbourhood. As we witness Tom and Maggie packing up a moving truck, the two finally seem at peace. However, in the final scene, as the family drives to their new home, the comfortable resolution of the narrative is undermined, as in all of the films covered in Section One. Tom glances at his son in the rearview mirror, and we see Jake sitting in the backseat. He is staring out the window as house after house flashes past, all red brick two-storey dwellings that 
appear ceaselessly identical in their imaging of the façade of comforting suburbia. As Jake watches the procession of houses, a cacophony of whispers overtakes the soundtrack. The whispers become increasingly desperate and vociferous, yet the words themselves remain largely indistinguishable - a carnivalesque evocation of traumatic experience. Though no single voice is particularly comprehensible in this polyphony, it is clear they are all desperate to be heard, as the whispers crescendo until they sound more like an abject babble of moans and groans. In the film's final shot, Jake slowly and calmly covers his ears in a futile attempt to shut these voices out.

Thus, the viewer is confronted with the awareness that no matter where the Witzky's move, the child will be endlessly inundated with the terrible secrets of aggrieved ghosts. It becomes clear that Jake and his father could never possibly resolve the demands of all these unquiet spirits: the process is overwhelmingly never-ending, and points to the corruption underlying adult society as a whole. As the film cuts to black, a voice before the credits commence sings the childish chant 'Na na na na na na': a taunt to the viewer that our time spent invested in Tom's quest to reinstate the delineation between past and present, the ghosts and the living, suppressed violence and domestic bliss has not successfully restored stable borders of meaning and existence. Jake is the embodiment of this lingering symbolic rupture.

\section{'It's not the house that's haunted. It's your son': Approaching The Further in Insidious}

Released ten years after Stir of Echoes and The SiXth Sense, Insidious (2010) contains the reverberations of each in its plot about a male protagonist (father Josh) being 'reacquainted' with a repressed part of his own being through uncovering his son Dalton's secrets. Insidious also self-reflexively recalls the three 1980 s films discussed in Chapter One: we are confronted with eerie female twins who look like grown-up versions of The Grady twins in The SHINING, a séance scene that closely follows a key set-piece of THE ChANGELING, and a story of a child lost in a spiritual realm that is a direct echo of that in Poltergeist (complete with an eccentric female psychic accompanied by two young male paranormal investigators armed with all manner of quirky equipment). Following the millennial wave of globally successful uncanny child films, Insidious indicates that the uncanny child trope started to become self-consciously augmented at the close of the 21st century's first decade. 
Early in the film, Dalton falls into a mysterious coma seemingly after tumbling from the stairs in the family home's attic. (However, the ominous creaking noises emanating from a dark corner of the attic suggest that the source of this noise is really behind the coma). Dalton's coma becomes the riddle that the adult protagonists, Dalton's mother Renai and his father Josh, must solve, as Dalton's body itself becomes a hieroglyph. As his parents take Dalton to the hospital, the child is positioned as an oddity to be scrutinized and decoded by the medical gaze in a similar manner to Danny in THE SHINING. As the doctor in INsIDIOUs proclaims, 'I've never seen anything like it', a horror film cliché which signals that Dalton's condition is not bound by the normal order and thus cannot be resolved through medical treatment.

The next scene is prefaced by the title ' 3 Months Later', and we learn that Dalton is still in the limbo-world of the coma and has been moved out of the hospital and back to the family home. Thus, while the everyday rhythms of time passing continue around him, Dalton remains fixed in a state of frozen a-temporality: a particularly unsettling state for a being defined according to the teleological process of growing up. The monstrousness of Dalton's bodily stasis is fetishized throughout the film. As Dalton is kept alive by feeding tubes and a life-support machine, his presence in the adult's everyday life is tied to the technological. His life is signalled by the rhythmic beeping of his life-support machine, which seems to taunt the neat chronological progression of analogous rhythms - like the large grandfather clock that stands outside his room - through marking a state of perpetual stasis. Notably, the 'ghosts' that Dalton's body invites into the family home, themselves abject images of frozen time in their stiff, doll-like aspects and aberrant movements, often appear alongside the grandfather clock as if mocking its obdurate, chronological rhythms.

Stuck in a mysterious coma, Dalton, echoing Carol Anne of POLTERGEIST, becomes a contradictory incarnation of the 'lost child': he is physically present, yet his mind and soul inhabit some impenetrable elsewhere to which his parents have no access. The fraught attempt to comprehend the essence of the child - that unknowable component of his otherness that threatens the adult's symbolic reality - is thus realized in this film via the quest to locate his soul. It is later explained by the psychic, Elise, that Dalton is a talented 'astral projector' and his soul has become lost in a realm of unquiet ghosts called 'The Further'. The name The Further hints at the elusive qualities of childhood in relation to the adult's psyche: it is a realm which is always just further than the adult's perceptions can reach. Elise explains that The Further is 'a world far beyond our own, yet all around us. A place without time as we know it.' Like adulthood's 'inner 
child', The Further constantly underlies the adult's present consciousness yet is simultaneously eternally beyond our grasp.

Dalton's comatose body is the portal through which signs of this place intrude upon the present. He thus displaces the process at the core of the traditional ghost story whereby the spectral world erupts at a particular site, associated with an unacknowledged trauma tied to that location, before disappearing once the traumas of the ghosts are resolved. All the films previously discussed in Section One are comprised of this structure, even though it is problematized in each by the child's eerie obstruction to cathartic narrative resolution. The deconstruction of this structure is openly dramatized in Insidious by the twist midway through (telegraphed in trailers and promotional material): as Elise explains, 'It's not the house that's haunted. It's your son.' The realm of the supernaturally charged unconscious that the child embodies and inhabits - this place where meaning collapses - cannot be escaped geographically. It is always there, just beyond the adult's view. Dalton exists as the adult's inescapable rem(a) inder of this realm.

Dalton's embodiment of the threatening return of the repressed is realized overtly through his entwinement with his father, Josh. Two-thirds into the film, we learn that Josh was also a talented astral projector as a child. As a result, throughout his childhood he was relentlessly pursued by the ghost of a decrepit old woman - the memory of which he has long since repressed. The impending reemergence of Josh's childhood memories is suggested by recurring grainy, black-and-white shots of Josh as a child sleeping as the camera floats upwards and towards his bedroom window. In fact, the film opens with such a shot, signalling that the father's own return to his buried past is a central quest of the film, albeit submerged until the third act. Josh's concealed inner child is evoked by a box of childhood photographs his mother has kept hidden from him throughout his adulthood. As Josh discovers when his mother shows him these photographs, the old woman's ghost appears in every photograph of Josh as a child.

The photographs thus literalize the uncanny resurfacing of Josh's inner child. A scene in which he and his wife Renai nervously pore over these longforgotten childhood photos reflects Damien Sutton's Deleuzian discussion of photography: 'like memory, photography constitutes a past as an other, and as with memory, we enter the photograph's "pastness" in order to make sense of the collapse of the "then" and "now" that it represents' (emphasis in original, 2009, 54). The faded tones of the photographs and their depiction of Josh as a child staring knowingly back at himself as an adult - an image of himself back 'then' casting an immobile yet penetrating gaze at 
Josh as he is 'now' - presages the imminent collision of these seemingly distinct realms. The 'then' of Josh's childhood and the 'now' of adulthood are bound to each other - Josh is, after all, the same person as the boy in the photographs - yet they are also impenetrably distant from each other. As Josh stares at the photographs and Renai asks if he remembers what is depicted in them, Josh blankly shakes his head and mutters 'No. I don't.' The ghostly figure in the photographs enhances the threatening otherness represented by his inaccessible former self. The ghost initially appears as an ambiguous distortion of the image, gradually becoming more visible in each successive photograph Josh looks at. Her gaze, while literally veiled, seems to be simultaneously directed towards both the child-Josh within the photograph and outwards towards the adult-Josh looking at the photographs. The ghost's gaze thus penetrates beyond the 'then' and 'now' border, auguring a simultaneous collapse in temporal and subjective boundaries.

The Further spatially represents adulthood's inner child. Dalton's soul has been trapped within The Further throughout the film, and, as we see when Josh first enters this shadowy dimension at the film's climax and comes face-to-face with himself as a child, it is also in these murky black depths that Josh's inner child resides. The Further is characterized by indeterminate spaces with no borders: Josh wanders through its inky gloom until he reaches the façade of the former family house, in which Dalton fell into the coma in the film's early scenes. In The Further version of the house, the dark, cavernous spaces and labyrinthine structure do not emit a direct reflection of the house with which we have already become familiar, although the structure and positioning of the staircase and rooms are the same. This is particularly apparent in the attic in which Dalton is trapped - a small, cramped space in the opening of the film, it now appears impossibly wide and high, a red-hued cavern with no clear borders. The house as it appears in The Further is an image of the unhomely par excellence, the familiar rooms now appearing as capacious spaces littered with exaggerated realizations of Dalton's childhood drawings, such as an elaborate rocking horse. Thus, the house reflects a dreamlike image of the past childhood realm with which Josh has just become reacquainted: a precise conflation of the adult's unconscious, his childhood past, and the uncanny child character external to him - his son - who exists as the crucible for both realms. Reinforcing The Further's existence at the interface of Josh's and Dalton's psyches, Josh's physical body is actually sleeping as he ventures into The Further - his journey is punctuated by shots that draw us back into the diegetic present in which his sleeping 
body jerks and jolts - suggesting that Josh has gained access to The Further through a process of hypnosis that peels back the conscious layers of his psyche. This is also a precise instance of the 'slackening of the sensorymotor connections' (Deleuze, 1997a, 3), which invites the emergence of the cinematic time-image.

The Further's status as an unconscious zone of pastness beyond progressive adult clock-time is highlighted by the different layers of the past which coexist within the same space. The space thus functions in a similar way to The Overlook hotel in THE SHINING. Dimly lit Elizabethanstyle paintings adorn the walls, while a child dressed in Victorian garb runs amok, and a doll-like 1950s-era family sit frozen in a neighbouring room. Appearing like mannequins with caricature-like grins, this family seem to stem from a stereotypical child's drawing like those that adorn Dalton's bedroom walls. Extending the personal implications of the child's uncanniness into the realm of the sociocultural, just as the innocence of Dalton's drawings appears menacingly disingenuous, the mannequin-esque 1950s family disrupt cultural nostalgia for an innocent lost past in their maniacal exaggeration of a traditional nuclear family. Furthermore, they monstrously empower the temporal disjunction of The Further. This is aesthetically rendered through these beings' defiance of coherent sensory-motor connections and bodily movement: they evoke in threatening form Deleuze's 'emancipation of time, which ensures the rule of impossible continuity and aberrant movement' (1997a, 39). When Josh desperately asks one of the doll-like female twins about the whereabouts of Dalton, the camera closes in on his face, and although he does not break eye contact with the apparition, she suddenly appears in the room behind him. Similarly, as Josh backs away from the family in horror, they remain fixed in their positions, only to suddenly appear standing before him without moving through a jump cut. The abject leers that appear on their faces also emerge through a jump cut, a violation of linear continuity in which the facial movement required to change from one expression to the other is omitted (Fig. 4).

The film as a whole eventually becomes consumed by The Further's threats to homogenous, linear clock-time. When Josh and Dalton finally escape The Further and make it back to the present, the family seem to be happily reunited and the spectral realm displaced. However, in the film's final moments, psychic Elise becomes suspicious of Josh and takes a photograph of him (as photography again becomes the intercessor between temporal and subjective realms). The viewer is not shown this photograph, but Elise is clearly terrified by what she sees. Josh becomes so enraged that 


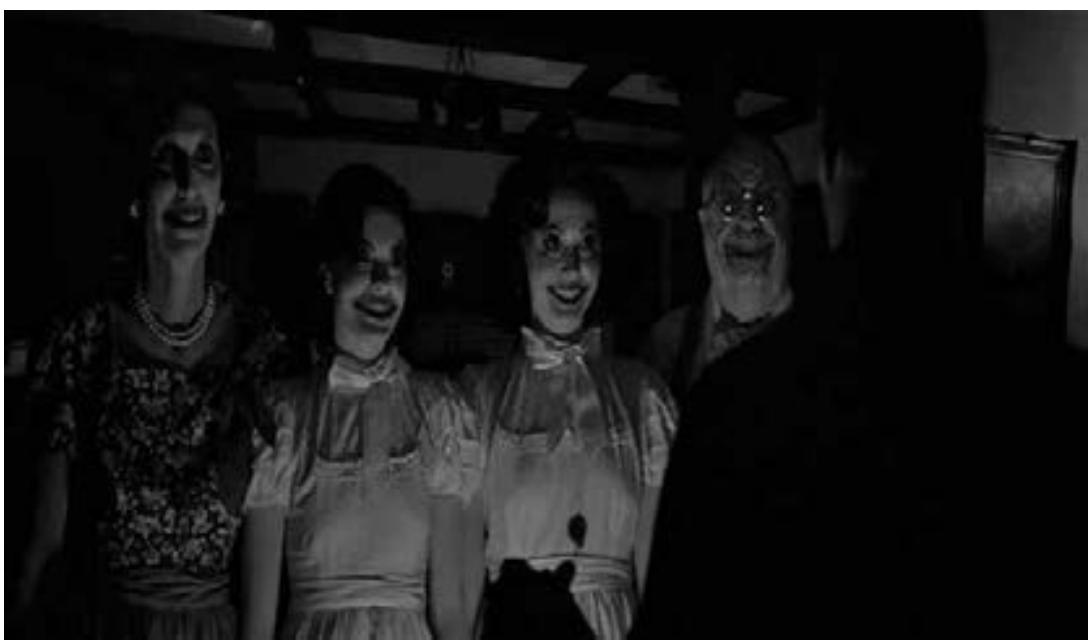

Figure 4. The doll-like 1950s-era family leer at Josh in The Further (INSIDIOUS).

Elise has taken his photograph without permission that he strangles her, leaving her face frozen in an expression of fear that aligns her with the immobile postures of the beings in The Further. When Renai enters the room and picks up the camera she is able to see the frightening vision that the photograph revealed to Elise: the ghostly old woman who haunted Josh's childhood has taken over Josh's adult self, as an image of the ghost's visage is superimposed upon his own face. Josh has been consumed by the childhood traumas - signified by the ghost woman - that were previously locked inside his repressed inner child.

The film ends abruptly on a close-up of Renai's terrified face as she turns around to face Josh, before cutting to an extended black screen. From this black screen, the film's title emerges, identical in appearance to that which opened the film and accompanied by the same dissonant violin shrieks. Prior to this, the movement in the close-up on Renai's face slows down to the point that the shot almost becomes a freeze-frame. This, coupled with the cut to black and sudden reversion to the film's first few seconds, enunciates with finality the threat to chronological continuity evoked initially by the child's coma. In the final moments, the film seems to become 'stuck' before looping back to its opening moments. Actualizing the breakdown in linear time threatened by the coma-frozen Dalton, The Further, the ghost from Josh's childhood past, and the photographs throughout the film - and the subsequent dissolution between the borders of 'then' and 'now' - the film's own chronological narrative progression abruptly comes undone in the final shot. 


\section{Conclusion}

While the narratives of each of these films attempt on a surface level to resolve the enigmas of their uncanny children, these characters somehow resist functioning as riddles that can be solved by the adult protagonists and viewers, their vaguely threatening otherness preserved just outside the bounds of a secure symbolic framework. In more overt and precise ways than in the 1980s films, in The SiXth SenSe, Stir of Echoes, and Insidious, the uncanny child character reawakens the adult's traumatized inner child, suggesting a tangled relationship between child and adult subjects that in turn unsettles the boundaries between past and present. Drawing back to Freud's discussion of an imagined Rome in which all developments of the past stand alongside those most recent - outlined in Chapter One - Freud remarks that:

if we wish to represent a historical sequence in spatial terms, we can do so only by juxtaposition in space, for the same space cannot accommodate two different things. Our attempt to do otherwise [...] show[s] how far we are from being able to illustrate the peculiarities of mental life by visual means. $(2002,9)$

These ambiguously eerie children actualize such spatio-temporal 'peculiarities', imaging the process in which, to reiterate Stockton, 'past and present ego-structures [are put] side-by-side, almost cubistically, in lateral spread' $(2009,14)$.

Thus, these films suggest the extent to which contemporary American understandings of childhood continue to entangle the child with Freudinflected mythologies of the adult's unconscious. Yet, by self-reflexively augmenting this association, these films also imply that the child draws both a disruptive and constructive power from this seemingly adult-centric paradigm. These late 2oth- and early 21st-century American films start to consider the implications of the uncanny child's empowerment of traumatic temporalities that strain against adult-centric models of progressive chronological time - a particularly potent process amidst the uncertainties of millennial transition, as is further explored in Section Four. In their disruptions to linear narrative time and concomitant exposure of the illusory permanence and solidity of adult subjectivity, these uncanny children reconceptualize teleological conceptions of growth that place adulthood as a secure, complete end point to childhood's empty, naïve origins. In the next section discussing Spanish horror films, I demonstrate how the uncanny 
child also unhinges historical chronology in frightening but potentially liberating ways, as the child's spectral insight is extended into the realm of collective memory and national identity.

\section{Works Cited}

Ariès, Philippe. Centuries of Childhood:A Social History of Family Life. Trans. Robert Baldick. New York: Alfred A. Knopf, 1962. Print.

Caruth, Cathy. Unclaimed Experience: Trauma, Narrative, and History. Baltimore: The John Hopkins University Press, 1996. Print.

Deleuze, Gilles. Cinema 2: The Time Image. 1985. Trans. Hugh Tomlinson and Robert Galeta. Minneapolis: The University of Minnesota Press, 1997a. Print.

Freud, Sigmund. Civilization and Its Discontents. 1930. Trans. David McLintock. New York: Penguin Books, 2002. Print.

Hantke, Steffen, ed. 'They Don't Make 'Em Like They Used To: On the Rhetoric of Crisis and the Current State of American Horror Cinema.' American Horror Film: The Genre at the Turn of the Millennium. Jackson: The University Press of Mississippi, 2010. vii-xxxii. Print.

Houtman, Carol. 'Questions of Unreliable Narration in The SIXTH SENSE.' Scope: An Online Journal of Film Studies Nov. 2004: n.p. Web. 30 Sep. 2014.

Jenkins, Philip. Moral Panic: Changing Concepts of the Child Molester in Modern America. New Haven: Yale University Press, 1998. Print.

Kendrick, James. 'A Return to the Graveyard: Notes on the Spiritual Horror Film.' American Horror Film: The Genre at the Turn of the Millennium. Ed. Steffen Hantke. Jackson: The University Press of Mississippi, 2010. 142-159. Print.

Kincaid, James. Erotic Innocence: The Culture of Child Molesting. Durham: Duke University Press, 1998. Print.

La Caze, Marguerite. 'The Mourning of Loss in The SiXth Sense.' PostScript:Essays in Film and the Humanities 21.3 (2002): 111-121. Web. 30 Sep. 2014.

Lavik, Erlend. 'Narrative Structure in The Sixth Sense: A New Twist in Twist Movies?' The Velvet Light Trap 58 (2006): 55-64. Project Muse. Web. 30 Sep. 2014.

Link, Stan. 'The Monster and the Music Box: Children and the Soundtrack to Horror.' Music in the Horror Film: Listening to Fear. Ed. Neil Lerner. New York: Routledge, 2010. 38-54. Print.

Natoli, Joseph. Speeding to the Millennium: Film and Culture, 1993-1995. Albany: State University of New York Press, 1998. Print.

Stockton, Kathryn Bond. The Queer Child, or Growing Sideways in the Twentieth Century. Durham: Duke University Press, 2009. Print.

Sutton, Damien. Photography, Cinema, Memory: The Crystal Image of Time. Minneapolis: The University of Minnesota Press, 2009. Print. 
Thrailkill, Jane F. 'Sigmund Freud, Pedophile Priests, and Shyamalan's Filmic Fairy Tale (The Sixth Sense).' Critical Approaches to the Films of M. Night Shyamalan: Spoiler Warnings. Ed. Jeffrey Weinstock. New York: Palgrave Macmillan, 2010. 139-158. Print.

Underwood, Ted. 'Romantic Historicism and the Afterlife.' PMLA. 117.2 (2002): 237-251. JSTOR Arts and Sciences III. Web. 30 Sep. 2014.

Walsh, Fintan. Male Trouble: Masculinity and the Performance of Crisis. New York: Palgrave Macmillan, 2010. Print.

Warner, Marina. Managing Monsters: Six Myths of Our Time. London: Vintage, 1994. Print.

Weinstock, Jeffrey, ed. 'Introduction: The Spectral Turn.' Spectral America:Phantoms and the National Imagination. Madison: University of Wisconsin Press, 2004. 3-17. Print.

Žižek, Slavoj. Looking Awry: An Introduction to Jacques Lacan Through Popular Culture. Cambridge: MIT Press, 1992. Print.

\section{Filmography}

The Changeling. Dir. Peter Medak. 1980. HBO Home Video, 2005. DVD.

EXISTEnZ. Dir. David Cronenberg. Alliance Atlantis Communications, 1999. Film. Eyes Wide Shut. Dir. Stanley Kubrick. Warner Bros., 1999. Film.

FALLEN. Dir. Gregory Hoblit. Atlas Entertainment, 1999. Film.

Fight Club. Dir. David Fincher. Fox 2000 Pictures, 1999. Film.

The Gift. Dir. Sam Raimi. Lakeshore Entertainment, 200o. Film.

The Haunting. Dir. Jan de Bont. DreamWorks SKG, 1999. Film.

House on Haunted Hill. Dir. William Malone. Dark Castle Entertainment, 1999. Film.

Insidious. Dir. James Wan. 2010. Icon Film Distribution, 2011. Blu-ray DVD.

Jaws. Dir. Steven Spielberg. Universal Pictures, 1975. Film.

Magnolia. Dir. Paul Thomas Anderson. New Line Cinema, 1999. Film.

The Matrix. Dir. Lily and Lana Wachowski. Warner Bros., 1999. Film.

Poltergeist. Dir. Tobe Hooper. 1982. Warner Home Video, 2008. DVD.

Scared Silent: Ending And Exposing Child Abuse. Dir. Melissa Jo Peltier, Perf. Oprah Winfrey. Arnold Shapiro Productions, 1992. TV Movie.

The Shining. Dir. Stanley Kubrick. 1980. Warner Bros. Entertainment Inc., 2007. Blu-ray DVD.

The Sixth Sense. Dir. M. Night Shyamalan. 1999. Hollywood Pictures Home Entertainment, 2000. DVD.

Star Wars Episode I: The Phantom Menace. Dir. George Lucas. Lucasfilm, 1999. Film. 
Stigmata. Dir. Rupert Wainwright. Metro-Goldwyn Myer, 1999. Film.

StiR OF EchOES. Dir. David Koepp. 1999. Lionsgate Home Entertainment, 200o. DVD. Thi13een Ghosts. Dir. Steve Beck. Warner Bros, 2001. Film.

The Thirteenth Floor. Dir. Josef Rusnak. Columbia Pictures, 1999. Film.

What Lies Beneath. Dir. Robert Zemeckis. DreamWorks SKG, 20oo. Film.

\section{Music}

Gob. 'Paint it Black' (Rolling Stones Cover). Comp. Mick Jagger and Keith Richards. How Far Shallow Takes You. Nuttwerk America, 1998. CD.

The Rolling Stones. 'Paint it Black.' Comp. Mick Jagger and Keith Richards. Aftermath. ABKCO Records, 2002. CD. 
